\title{
Güneş-Dünya-Ay Modeli Geliştirilmesi ve Fen Bilgisi Öğretmen Adaylarının Akademik Başarılarına Etkisi
}

\author{
İlda ÖZDEMİR ${ }^{1}$, İbrahim ÜNAL ${ }^{2}$ \\ 1 Tavas Milli Eğitim Müdürlüğü, Sait Kalaycıoğlu Ortaokulu, Denizli \\ ildaduskun@hotmail.com, http://orcid.org/0000-0002-9533-8826 \\ 2 İnönü Üniversitesi, Eğitim Fakültesi, Matematik ve Fen Bilimleri Eğitimi Bölümü, Malatya \\ ibrahim.unal@inonu.edu.tr, http://orcid.org/0000-0001-8497-4459
}

Received : 09.01.2020

Accepted : 07.04.2020

Doi: $10.17522 /$ balikesirnef.672370

Özet - Bu çalışmanın iki amacı vardır ve iki bölümden oluşmaktadır. Çalışmanın birinci bölümünde gerçek boyutlarından küçültülerek Güneş-Dünya-Ay modeli geliştirilmiş, ikinci bölümünde ise bu modelin öğretmen adaylarının astronomi başarıları üzerine etkisi araştırılmıştır. Öğretmen adaylarının astronomi başarılarındaki değişimi incelemek amacıyla Astronomi Başarı Testi geliştirilmiş, 60 öğretmen adayına ön test ve son test olarak uygulanmıştır. Öğrencilerin yarısına ilgili konular, standart öğretim ile anlatılırken, kalan yarısına ise geliştirilen model kullanılarak anlatılmıştır. Araştırmanın sonucunda modelle öğretimin öğrenme ve anlama bakımından önemli etkilere yol açtı̆̆ı görülmüştür.

Anahtar kelimeler: Güneş-Dünya-Ay Modeli, akademik başarı, öğretmen adayları, model geliştirme, astronomi eğitimi.

Sorumlu yazar: İbrahim ÜNAL, İnönü Üniversitesi, Eğitim Fakültesi, Matematik ve Fen Bilimleri Eğitimi Bölümü, Battalgazi, Malatya, ibrahim.unal@inonu.edu.tr

Bu çalışma İlda (DÜŞKÜN) ÖZDEMİ'in yüksek lisans tezinin bir bölümünden üretilmiş olup, bu tez İnönü Üniversitesi Bilimsel Araştırma Projeleri (BAP) Birimi tarafından 2010/93 numaralı proje ile desteklenmiştir.

\section{Geniş Özet}

\section{Giriş}

Astronomi; üst düzey düşünme ve hayal gücü kullanma gibi yetenekleri gerektiren ve bu nedenle de modellerin sıklıkla kullanılabileceği bir bilim dalıdır. Astronomi konuları, okullardaki en popüler konular arasındadır (Lelliott ve Rollnick, 2010). Okullarda kullanılan 
geleneksel kitaplar, öğretmenleri klasik yöntemleri kullanmaya teşvik etmektedir. Bu noktada, kullanılan materyalin astronomi konularının gerçekten anlaşılmasına yardımcı olup olmadığı problemi ortaya çıkmaktadır (Kikas, 1998). Aslında astronomi kavramlarını edinmedeki genel problem, astronominin sadece deneysel bir bilim olması değil, aynı zamanda gözlemsel bir bilim de olmasıdır. Dünya-Güneş-Ay gibi gök cisimlerinin arasındaki dinamik ilişkileri doğrudan anlamak amacıyla bu objeler üzerine deney yapmak imkânsızdır. Problemin üstesinden gelmek ve bilimsel anlamlandırmalar sağlamak için öğretim sürecine modelleme ilave edilerek daha doğru daha güçlü kavramsal değişim ve daha derin anlaş1lırlıklar yaratılabilir (Frede, 2008). Çünkü öğrenciler; göremediği, işitemediği, dokunamadığg olguları anlamlandırmakta güçlük çekmekte ve olgu ile mevcut bilgileri arasında bă̆ kuramamaktadırlar. Oysaki soyut olgular grafiklerle, sembollerle, resimlerle ya da üç boyutlu modellerle anlatılırsa öğrenciler, olguyu gözlemleme ve inceleme firsatına erişmiş olacaklardır. Böylece soyut olan olgu, öğrencinin elle tutup gözle göreceği hale gelecek yani somutlaşacaktır (Balkan, 2007; Güneş ve Çelikler, 2010; Gözmen, 2008; Koçak, 2006; Minasl1, 2009; Sarıkaya, Selvi ve Doğan Bora, 2004; Zeynelgiller, 2006).

\section{Metot}

Yapılan bu çalışmada; astronomi dersinin temel konularının anlatımında kullanılabilecek, gerçek boyutu ölçekli olarak mümkün olan en iyi şekilde küçülterek özgün bir model geliştirilmiş ve bu modelin kullanımının öğrenci başarısı üzerindeki etkisi incelenmiştir. Bu nedenle çalışma, soyut bir içeriğe sahip olan astronomi dersindeki materyal ihtiyacını karşılaması ve bu materyalin akademik başarıyı olumlu yönde etkilemesi bakımından önem teşkil etmektedir. Dolayısıyla çalışmanın iki boyutu vardır. Çalışmanın birinci kısmında Güneş-Dünya-Ay modeli geliştirilmiş, ikinci kısmında ise modelin astronomi öğrenimindeki başarıya olan etkisi incelenmiştir.

Araştırmada Fen Bilgisi öğretmen adaylarının “Güneş, Dünya ve Ay’ın gerçek ve görünür hareketleri ve bu hareketlerin doğurduğu sonuçlar” konusuna ait başarılarını ölçmek ve karşılaştırmak için başarı testi kullanılmıştır. Test hazırlanırken kapsam geçerliğini sağlamak amacıyla belirtke tablosu oluşturulmuştur. Sorular uzman görüşü alınarak araştırmacı tarafından geliştirilmiştir. Hazırlanan 23 soruluk testin pilot uygulaması astronomi dersini alan Fen Bilgisi Öğretmenliği Lisans Programı'na devam eden öğretmen adayları ile yapılmıştır. Başarı testinin madde analizi Item and Test Analysis Program (ITEMAN Version:3) ile yapılmış ve ayırt edicilik indeksi 0,20'nin altında olan maddeler testin kapsamına alınmamıştır. Yapılan bu işlem sonunda başarı testinde toplam 18 madde kalmıştır. 
Bu 18 maddeden 4'ü “Ay ve Ay’ın evreleri”, 8'i “Güneş’in, Dünya'nın görünen-gerçek hareketleri ve eksen eğikliği, eliptik yörünge”, 6’s1 "Ay ve Güneş tutulmaları" ile ilgilidir. Testin KR20 güvenirlik katsayısı 0,629 olarak belirlenmiştir.

Araştırmada, Fen Bilgisi Öğretmenliği Lisans Programı'nda okutulan Astronomi dersi konularının anlatımında kullanılmak üzere bir Güneş-Dünya-Ay modeli geliştirilmiştir. Bu modelin yapılması için Bilimsel Araştırma Projeleri Birimi (BAP)'ne proje sunulmuştur. Geliştirilen modelin sahip olduğu özellikler aşağıdaki gibidir:

- Güneş kendi ekseni etrafında dönmektedir.

- Dünya kendi ekseni etrafında dönmektedir.

- Ay kendi ekseni etrafında dönmektedir.

- Ay, eliptik düzleme $5,145^{\circ}$ eğik olan düzlemdeki yörüngesi üzerinde Dünya etrafında dairesel yörüngede dönmektedir.

- Ay, Dünya ile birlikte Güneş’in etrafında eliptik yörüngede dönmektedir.

- Her üç cisim de hem kendi eksenleri etrafinda hem de diğer cisimlerin etrafinda saat yönüne ters yönde dönmektedir.

Ön test-son test kontrol gruplu yarı deneysel desenin kullanıldı̆̆ı araştırmanın evrenini, 2010-2011 eğitim öğretim yılı bahar dönemi Fen Bilgisi Öğretmenliği Lisans Programı’na devam eden 4. sınıf öğrencileri, örneklemini ise bu evrenden seçilen 60 öğrenci oluşturmaktadır. Bu 60 öğrenciden 30’u deney, 30’u kontrol grubunu oluşturmaktadır. 60 öğrenciye “Güneş, Dünya ve Ay’ın gerçek ve görünür hareketleri ve bu hareketlerin doğurduğu sonuçlar” konularıyla ilgili ön test-son test uygulanmıştır. İlgili konular kontrol grubuna, standart öğretim ile anlatılırken, deney grubuna ise geliştirilen model kullanılarak anlatılmıştır.

Deneysel öğretim fizik laboratuvarında gerçekleştirilmiştir. Konular, öğrenci-öğretmen ve öğrenci-öğrenci şeklinde karşılıklı fikir alışverişlerinin yapıldığı sınıf tartışması şeklinde ele alınmıştır. Konular, model üzerinde öğretmen adaylarına anlatılmıştır. Öğretim esnasında öğretmen adaylarının, günlük yaşantıda geçirdikleri deneyimler ile ilgili fikirleri alınmış, sonrasında araştırmacı tarafından anlamlandırmada zorluk çekilen noktalar ipucu verilerek ya da anlatılarak açıklanmıştır.

Standart öğretimde, temel astronomi ile ilgili kitabi bilgilere ve ders notlarına bağlı kalınmıştır. Temel astronomi konularıyla ilgili her kavram araştırmacı tarafından tarif edilmiş, önemli olan kavramlar tahtaya yazılmıştır. Ay’ın evrelerini gösteren şekiller, Ay ve Güneş 
tutulmasını gösteren şekil ve 21 Haziran, 21 Aralık, 21 Mart ve 23 Eylül tarihlerinde Dünya'nın konumu iki boyutlu şekilde tahtaya çizilmiştir. Öğrenciler de tahtadaki şekilleri defterlerine çizmiş ve anlayamadıkları kısımları herhangi bir materyal olmaksızın sözel olarak açıklanmıştır. Her konu önce sözel olarak anlatılmış sonrasında ise önemli kısımlar öğrencilere not tutturulmuştur. Öğrencilerin derse katılımı, araştırmacının sorduğu soruları cevaplamakla sınırlı olmuştur.

\section{Sonuç}

Araştırmadan elde edilen sonuçlar; deney ve kontrol gruplarının ön test puanları bakımından farklılaşmadığını, son testte ise deney grubunun, kontrol gurubuna göre puan ortalamaları açısından daha başarılı olduğunu göstermiştir. Buna ek olarak astronomi başarı testinde yer alan “Ay’ın evreleri”, “Dünya'nın Güneş etrafında hareketi”, “Eksen eğikliği ve Dünya'nın Güneş etrafında hareketi” ve "Eksen eğikliği” konularına yönelik olarak sorulan sorularda doğru cevap frekansının deney grubu lehine olması, deney grubunda kullanılan Güneş-Dünya-Ay modelinin, üç boyutlu ilişkileri algılamaya, soyut ve üç boyutlu düşünmeye dayanan bu tür konuların anlaşılırlığını artırdığını ortaya koymaktadır.

\section{Tartışma ve Öneriler}

Araştırmadan elde edilen istatistiksel sonuçlara ek olarak geliştirilen modelin literatür taraması neticesinde benzerine rastlanmadığı görülmüştür. Geliştirilen bu modelle öğrenmede zaman kısalmış ve öğrencinin sürece aktif katılımı sağlanmış olacaktır. Böylelikle yanına gidilmesi ve sınıfa getirilmesi mümkün olmayan olay, olgu ve varlıkların daha iyi anlaşılması sağlanmış olacaktır. Yapılan bu çalışma sayesinde geliştirilen Güneş-Dünya-Ay modelinin bu alanda geliştirilecek modellere fikir vereceği ve yapılan çalışmanın ise eğitim materyali kullanmanın öğrenci başarısına etkisini inceleyecek diğer çalışmalara 1 şı tutacağ düşünülmektedir. 


\title{
The Effect of a Developed Sun-Earth-Moon Model on the Academic Achievement of Pre-service Science Teachers
}

\author{
İlda ÖZDEMİR ${ }^{1}$, İbrahim ÜNAL ${ }^{2}$ \\ ${ }^{1}$ Tavas National Education Directorate, Sait Kalaycıoğlu Secondary School, Denizli, \\ ildaduskun@hotmail.com, http://orcid.org/0000-0002-9533-8826 \\ 2 İnönü University, Faculty of Education, Department of Mathematics and Science \\ Education, Malatya, ibrahim.unal@inonu.edu.tr, http://orcid.org/0000-0001-8497-4459
}

Received : 09.01.2020

Accepted : 07.04.2020

Doi: $10.17522 /$ balikesirnef.672370

Abstract - This study composed of two parts with two main purposes. In the first part of the study the Sun-EarthMoon Model was developed by miniaturizing from their real size and in the second part the effect of this model on the astronomy achievement of preservice science teachers was investigated. In order to examine the changes in the achievement of preservice science teachers, an Astronomy Achievement Test was developed and applied to 60 preservice science teachers as pre-test and post-test. Half of the pre-service science teachers received standard instruction that based on board-chalk-textbook. The rest of them received experimental instruction that taught by using the developed model. As a result of the research, it was seen that the experimental group which was teaching with the model had significant effects in terms of learning and understanding compared to the control group.

Key words: Sun-Earth-Moon Model, academic achievement, pre-service science teachers, development of model, astronomy education.

Corresponding author: İbrahim ÜNAL, İnönü University, Faculty of Education, Department of Mathematics and Science Education, Battalgazi, Malatya, ibrahim.unal@inonu.edu.tr

This article was produced from a part of İlda (DÜŞKÜN) ÖZDEMIR's thesis, which was supported by İnönü University Scientific Research Projects Coordination Unit with the project numbered 2010/93.

\section{Introduction}

Intangible and complex context of science has made models used in science teaching indispensable. The studies carried out by Baloğlu-Uğurlu (2005), Bostan (2008), Tunca (2002) and Ünsal, Güneş and Ergin (2001) showed that misconceptions formed at the primary years of education continue until college years and students learn various astronomy concepts wrongly because of incorrect and missing information in the textbooks. 
Misconceptions in that students first learned is permanent and these continue throughout the students' next learning life. An example related to the persistence of first information was presented in the longitudinal study which carried out in 1998 by Kikas. He investigated the impact on astronomical concepts such as seasonal changes, axial tilt, day/night cycle of textbook-based traditional teaching. The results revealed that, after teaching, the students described and remembered the scientific expressions quite well, and four years later the same students used their previous concepts to explain the target concept and their answers were similar to younger children (Kikas, 1998).

Students have difficulties in making sense of the phenomenon that they cannot see, hear or touch, and cannot make a connection between the case and the present information. If such abstract phenomena are explained by visual materials or models, students will have opportunity to observe and examine the phenomenon and the abstract phenomenon will become visible for students (Balkan, 2007; Gözmen, 2008; Güneş \& Çelikler, 2010; Koçak, 2006; Minasl1, 2009; Sarıkaya, Selvi \& Doğan-Bora, 2004; Zeynelgiller, 2006).

In these national studies for astronomy education, usually misconceptions and knowledge levels of students in astronomy were estimated and the result that using of training material in astronomy teaching increased achievement and requirement of material usage revealed. Bostan (2008) examined ideas for astronomy concepts and events of 974 students (10 to 23 years) who have got different education levels. Baloğlu-Uğurlu (2005) investigated misconceptions related to the Earth and the universe of the sixth grade students. Tunca (2002) searched error and lack of information for astronomy concepts in Geography, Physics and Science courses and in the study. Ünsal et al. (2001) examined university students' basic astronomy knowledge levels. Balkan (2007), Gözmen (2008), Günbatar and Sarı (2005), Koçak (2006), Minaslı (2009), Sarıkaya et al. (2004) and Zeynelgiller (2006) have revealed that the use of materials increases students' achievement. Kurtkaya (2010) intended to demonstrate the necessity of geography classrooms that equipped with materials.

Context of international studies for astronomy education are roughly as follows: Samarapungavan, Vosniadou and Brewer (1996) investigated mental models of students about the Sun-Earth and Moon. Kikas (1998) investigated the effect of teaching and retention of explanations and definition about astronomy. Vosniadou, Skopeliti and Ikospentaki (2004) investigated the way of logic and knowing in basic astronomy. Frede (2008) examined the effect of textbook-based and application-based methods in the acquisition of seasons and Moon phases. Chiras and Valanides (2008) searched the mental models of students related to 
day-night cycle. Ogan-Bekiroğlu (2007) investigated the effect of model-based teaching for Moon, Moon phases and other concept related to Moon. Subramaniam and Padalkar (2009) investigated the establishment of the issues with constructed models for Moon phases, their's transformation and logic. Falcao et al. (2004) conducted a case study to describe basic atronomy concepts in astronomy museum which has been models in there. Lee, Jonassen and Teo (2011) searched the role in conceptual change of developing model of students. Taylor, Barker and Jones (2003) examined the importance of to improve of mental model creating in astronomy education. Diakidoy and Kendeou (2001) compared the effect of standard instruction and experimental instruction (using model) to create conceptual change.

According to the above-mentioned literature, thanks to this study, a model which need for teaching of difficult concepts in astronomy context has been developed to fill the gap in the field of astronomy education and this model has been used in astronomy teaching. In this study, Sun-Earth-Moon Model was developed by miniaturizing from their real size in order to teach the fundamental concepts of Astronomy and it was identified the impact of using this model on students' achievement. Therefore, this study has got great importance because the present study serves materials needs for the related concept in Astronomy which has got an intangible content and has got the positive impact of this material in terms of academic achievement.

\section{Astronomy Teaching}

It is known that the most teachers are very attached to the textbook. Traditional books encourage the teachers to use lecture, questions and answers as instructional tools. While teachers present the definitions and explanations, the task of the students is to remember to produce answers and evaluate the questions. The real problem is whether the type of teaching is sufficient to provide meaningful learning (Kikas, 1998).

Astronomy has been a popular topic in school curricula for many years. Most cultures have put forward various ideas about events in the sky. However, the events observed can be understood by simple scientific explanations. For example, it is only a reminder that the Earth's distance from the Sun changes throughout the year. The main reason is a combination of Earth's orbit and axis tilt and spherical nature (Lelliott and Rollnick, 2010).

Students' prior knowledge and beliefs are resistant to time and do not conform to the scientific concepts given by instruction. Therefore, students' prior knowledge should be taken into consideration during the teaching process. It is important to note that students should 
construct their own knowledge (Frede, 2008). But younger children tend to develop nonscientific preliminary models because they are exposed to ideas about various phenomena from their own culture (Samarapungavan et al., 1996).

One of the problems that arise in the learning of astronomy is that it is not only experimental but also an observational science. Experimenting with astronomical objects is quite limited since it is not possible to examine or observe them closely. By using preknowledge and adding modeling, we can create more accurate, more powerful conceptual change and deeper understanding (Frede, 2008).

Models and modeling have an important place in science applications. Modeling activities such as analogies, metaphors and mathematical formulas are directly related to the production of scientific knowledge. This perspective has increased the importance of models and modeling in science education (Falcao et al., 2004). Clark and Mathis (2000) suggest that models enable individuals to see scientific processes first hand and that models greatly increase students' ability to solve problems in biology; Pringle (2004), on the other hand, states that models provide understanding of unobservable concepts such as the structure of the atom.

Models and modeling are often used by astronomers to understand and accurately provide phenomena.

To make children think like astronomers teaching should be a process in which the mental models to which students' individual knowledge and concepts are consistently linked are approved and formed (Taylor et al., 2003). Model-based instruction is defined by Vosniadou, Ioannides, Dimitrakopoulou, and Papademetriou (2001) as one of the learning environments in which active learning is supported (Ogan-Bekiroğlu, 2007).

Frede (2006) showed that the conceptual perceptions of teacher's related basic astronomy concepts were limited. The researcher identified several practical activities that could help prospective teachers to develop their perceptions and construct scientific concepts as follows:

1. Modeling with balls and spheres to restructure the movements of the Sun-EarthMoon, lunar phases, eclipses, seasons and day-night cycles, etc.

2. Observation of celestial bodies throughout the day, if possible throughout the year.

3. Model construction by reducing actual scales. 
4. Use of documentaries about the properties of celestial bodies in the solar system for more knowledge questions.

When the literature is examined, it is seen that teachers develop their understanding of basic astronomy issues in studies using three dimensional models (Lelliott and Rollnick, 2010). Taber (2001) also stated that scaled models make unfamiliar phenomena clear by making abstract ones physical.

\section{The Present Study}

The real and apparent motions of the Sun, Earth and Moon, which are part of the astronomy course, were instructed to the experimental and control groups for 3 weeks. Instruction was given to both groups by the first author. Related concepts were taught to the control group with standard instruction in the classroom. In the experimental group, astronomy course was taught in the laboratory by using model and the students answered the questions by examining the model.

In this study, quasi-experimental design with pretest-posttest control group was used. The Astronomy Achievement Test (ABT) was applied to all preservice teachers as a pre-test before application. The same test (ABT) was applied as a post-test to experimental and control group students after the application.

\section{Methodology}

\section{The Sample}

The sample of the study consists of 60 students from 4th grade preservice science teachers in spring semester of the 2010-2011 academic year. Half of these teacher candidates were systematically assigned to the experimental group and the remaining half to the control group.

\section{Assessment Instrument}

In this research, achievement test was used to participants in the experimental and control group in order to measure and to make comparison their achievement about the concept "the real and the apparent motions of the Sun-Earth-Moon system and the consequences of these motions".

During the preparation of the test, an indicator chart was created to ensure the validity of the content. After literature was investigated, questions were developed by the researchers 
and then presented to expert opinion. The pilot application of the test was conducted with 4th grade science teaching students who had taken the astronomy course before. Item analysis of the achievement test was performed with Item and Test Analysis Program (ITEMAN Version: 3 ) and items with a discrimination index of less than 0,20 were not included in the scope of the test. A total of 18 items remained in the achievement test. 4 of these 18 questions are related "the Moon and the Moon phases", 8 of them are related "the Sun, the Earth's appearreal motions and tilt, elliptical orbit", 6 of them are related "lunar and solar eclipses". In the result of analyzing to Astronomy Achievement Test with Item and Test Analysis Program (ITEMAN Version: 3), The KR20 reliability coefficient, mean difficulty and discrimination index were found to be $0.629,0.567$ and 0.481 , respectively. The discrimination and difficulty indexes of the test are given in Table 1.

Table 1 Results of the Analysis of the Items in Astronomy Achievement Test

\begin{tabular}{cccccc}
\hline $\begin{array}{c}\text { Item } \\
\text { no }\end{array}$ & $\begin{array}{c}\text { Difficulty } \\
\text { index }\end{array}$ & $\begin{array}{c}\text { Discrimination } \\
\text { index }\end{array}$ & $\begin{array}{c}\text { Item } \\
\text { no }\end{array}$ & $\begin{array}{c}\text { Difficulty } \\
\text { index }\end{array}$ & $\begin{array}{c}\text { Discrimination } \\
\text { index }\end{array}$ \\
\hline 1 & 0,300 & 0,402 & 10 & 0,667 & 0,364 \\
2 & 0,300 & 0,463 & 11 & 0,683 & 0,563 \\
3 & 0,550 & 0,661 & 12 & 0,867 & 0,630 \\
4 & 0,433 & 0,388 & 13 & 0,683 & 0,399 \\
5 & 0,517 & 0,436 & 14 & 0,667 & 0,335 \\
6 & 0,683 & 0,488 & 15 & 0,750 & 0,367 \\
7 & 0,500 & 0,505 & 16 & 0,400 & 0,675 \\
8 & 0,650 & 0,546 & 17 & 0,567 & 0,474 \\
9 & 0,450 & 0,316 & 18 & 0,533 & 0,648 \\
\hline
\end{tabular}

\section{Teaching Material}

In this study, a Sun-Earth-Moon Model has been developed to explain "the real and the apparent motions of the Sun-Earth-Moon system and the results of these motions", has been developed. Project presenting to Scientific Research Projects Coordination Unit has been accepted to design this model. Specifications of the developed model (axial and orbital motions, rotation periods, axial and orbital tilts of the Sun, Earth and Moon), comparison of these features with real mean diameters and distances, numerical data for model and limitations of the model is given by Ünal \& Özdemir (2016). The images of the model are given in figures below. 


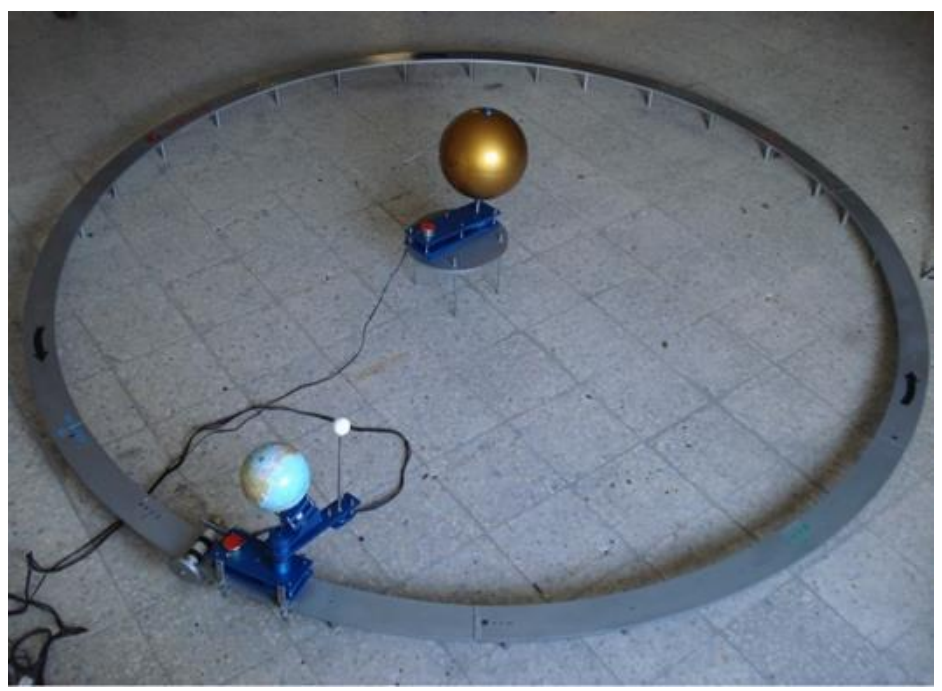

Figure 1 Sun-Earth-Moon Model

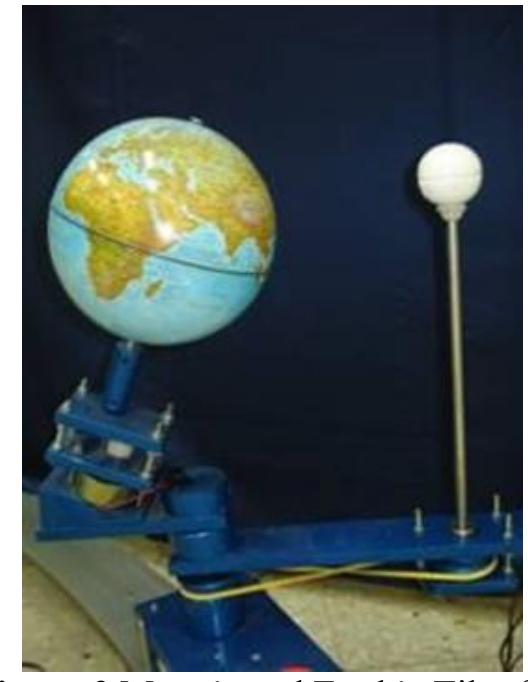

Figure 2 Moon's and Earth's Tilt of Axis

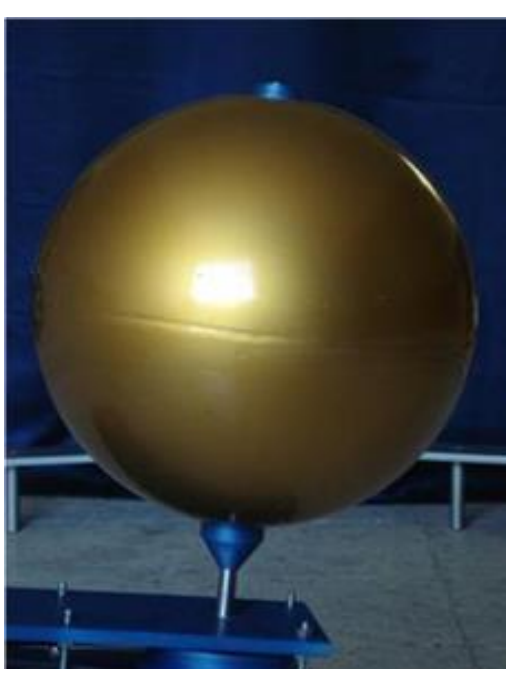

Figure 3 Sun's Tilt of Axis

\section{Procedure}

The plan of the study is as follows:

- Pilot implementation of the AAT that consisting 23 questions was conducted and 18 questions remained at the end of this process.

- Project was given Scientific Research Projects Coordination Unit for the development of the Sun-Earth-Moon Model which will use in astronomy course. After accept of submitted the Project, Sun-Earth-Moon Model has been developed.

- Required legal permissions were taken for the course described by the researcher.

- Before the implementation, prepared AAT was applied to the pre-service science teachers.

- Control and experimental groups were described "the real and the apparent motions of the Sun-Earth-Moon", a concept of basic astronomy for 3 weeks. Problems which could arise 
from narrator's individual differences were eliminated by explaining concepts in both groups by the same person (that is: Investigator).

- After ending the application, prepared AAT, was applied to the pre-service science teachers.

\section{Experimental Instruction}

Experimental instruction was performed in the physics laboratory. Concepts were discussed in the form of class discussions which are conducted exchange of ideas in the form of student-teacher and student-student. Courses were conducted with the Sun-Earth-Moon Model in the Physics Laboratory which was given the above features and is shown in Figure 1. Concepts based on basic astronomical knowledge were described to pre-service science teacher on model. Firstly, by asking students for experiences which passed in daily life such as Night and day formation, changing of the Moon's shape during a month, the seasons and their ideas were gotten. Secondly teacher was explained by giving clue to the students when they had difficulty or by giving the explanation to the students.

When the phases of the Moon were explained, models were used for concepts which was confusing and had difficulty at understanding. According to the angle of incidence of the Sun's rays, students described the case by stopping model from time to time to tell how the Moon appears in different forms in different phases, when the Moon revolves around the Earth. When question (Why doesn't lunar eclipse or solar eclipse occur in the every full moon and new moon?) was answered, model was stopped in the related phases during revolution of the Moon on the model. Case which the Moon rises and sets with the Sun at the same time in the New Moon was shown on the model and the Moon fully enlightens in the full Moon because of the Moon's orbit was shown on the model. During the description of seasons, concepts such as Earth's solar rays acceptance angle, the Earth's distance to the Sun and lightdark portions of the hemispheres were discussed as stopping model at 21 June, 21 December, 21 March and 23 September points which were marked by the researcher on the rail when the Earth revolves around the Sun on the rail system. Teacher gave the necessary information when students faced with dilemmas and had difficulty during explanation. When eclipses were described, the model observed the moment when Sun-Earth-Moon come to the same line, by stopping movement of model. Lunar and solar eclipses were described on the model.

\section{Standard Instruction}

Standard teaching depended on the basic astronomy textbook information and notes. Every concept was described by the teacher. Important concepts were written on the board. 
Shapes that show the Moon phases and lunar-solar eclipses and the position of Earth at the dates of 21 June, 21 December, 21 March and 23 September were drawn on the blackboard by teacher in two-dimensional shapes. Students also drew these shapes on their notebooks. When students asked, teacher described verbally without any material. Firstly, each concept was described verbally, and then important parts of them were written on the students' book. During the lecture, some questions asked by the teacher were tried to be answered with students' verbal responses. Students' participation was limited to answering questions.

\section{Results}

The data obtained from this study were entered into the database in SPSS 17.0 program. Initially, Kolmogorov-Smirnov test were made to data. When the results were examined, to be normally distributed data were appeared.

Table 2 Obtained from Kolmogorov-Smirnov Test Z and P Values

\begin{tabular}{lccc}
\multicolumn{4}{c}{ Toward Experimental and Control Groups } \\
\hline Groups & Tests & $Z$ & $P$ \\
\hline \multirow{2}{*}{ Control Group } & Pre-test & 0,99 & 0,28 \\
& Post-test & 1,02 & 0,25 \\
Experimental & Pre-test & 1,05 & 0,22 \\
Group & Post-test & 0,80 & 0,54 \\
\hline
\end{tabular}

The data related to the statistical analysis of the scores obtained from the pre and post tests are given in the following table.

Table 3 Independent T-Test Results Toward Pre-Test Scores

\begin{tabular}{lccccc}
\hline Group & $N$ & $\bar{X}$ & $s d$ & $t$ & $p$ \\
\hline Experimental Group & 30 & 31,85 & 17,56 & \multirow{2}{*}{1,45} & \multirow{2}{*}{0,15} \\
Control Group & 30 & 26,11 & 12,65 & & \\
\hline
\end{tabular}

While the experimental group's pre-test score mean is 31,85 and this group's standard deviation is 17,56 , the control group's pre-test score mean is 26,11 and this group's standard deviation is 12,65 (see Table 3). As shown in Table 2, the mean score of the experimental group was 5,74 points higher than the control group. This difference is not statistically significant because of $p>0,03$. Therefore, the experimental and control groups can be considered as equivalent as regards to their success and readiness level. This case suggests that the selected groups comply with purpose of study (Figure 4). 


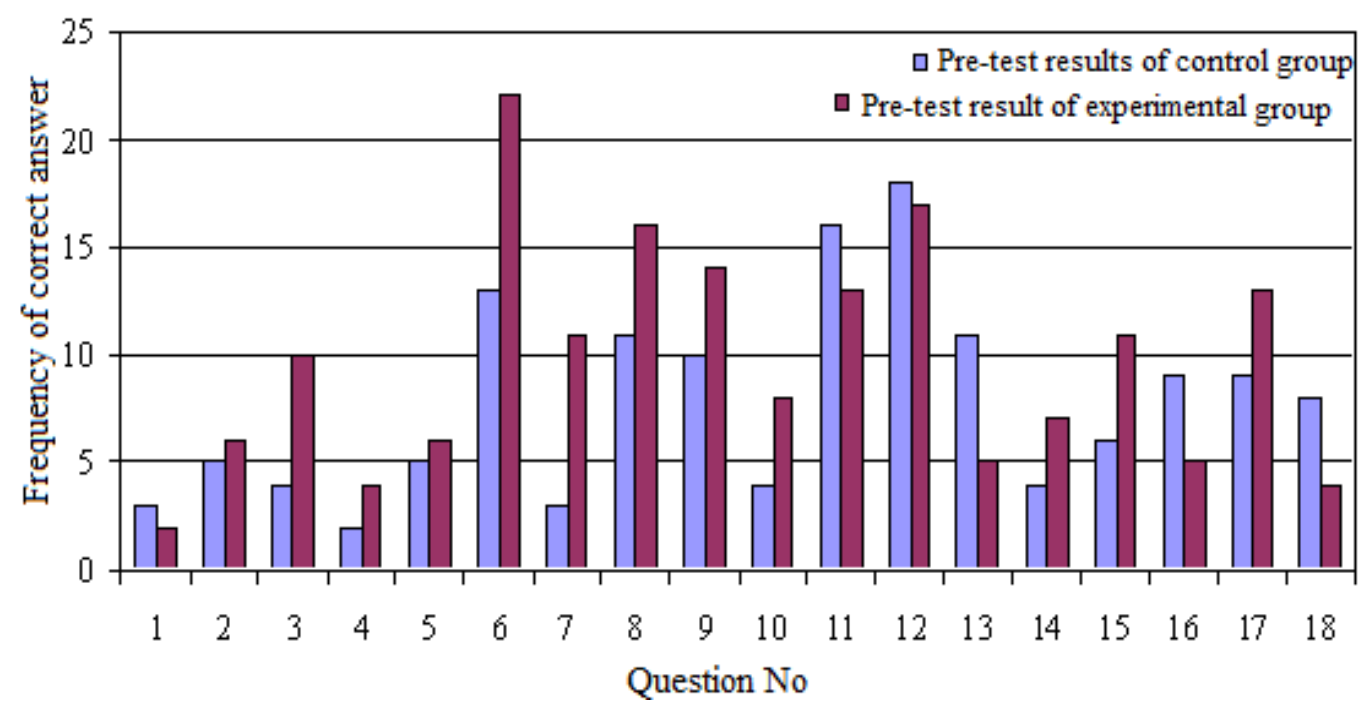

Figure 4 Pre-test Frequency of Correct Answer of Experimental and Control Groups Students According to Question Number

Table 4 Dependent T-Test Results of Control Group

\begin{tabular}{lccccc}
\hline Control Group & $N$ & $\bar{X}$ & $s d$ & $t$ & $p$ \\
\hline Pre-Test & 30 & 26,11 & 12,65 & $-6,99$ & 0,00 \\
Post-Test & 30 & 50,93 & 16,12 & & \\
\hline
\end{tabular}

Control group's pre-test score mean is 26,11 and standard deviation is 12,65 , post-test score mean's is 50,93 and standard deviation is 16,12 (see Table 4). It is seen that the difference between the mean scores of the post-test and the pre-test scores of the control group is 24,82 . This difference is statistically significant because of $p<0,03$. The results obtained at the end of the application show that the standard instruction is effective.

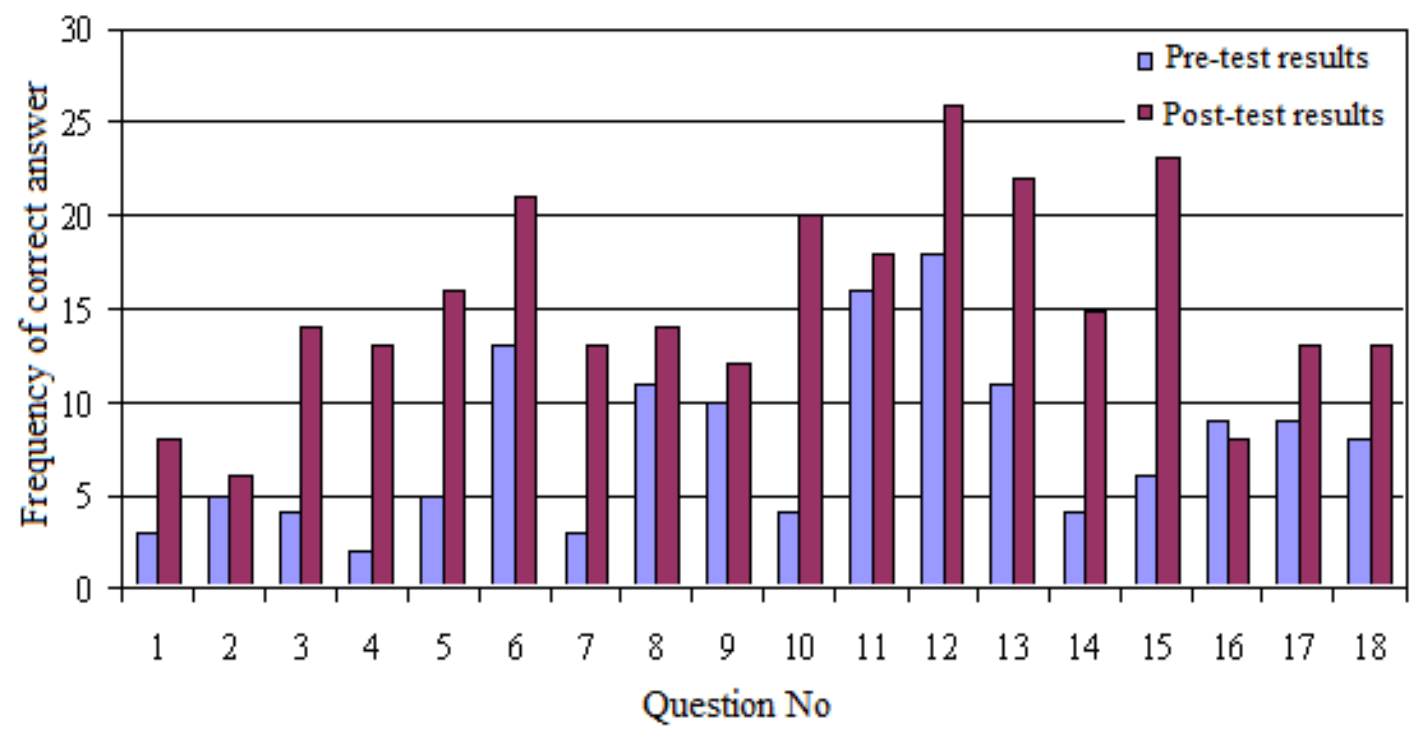

Figure 5 Pre-test and Post-test Frequency of Correct Answer of Control Group Students According to Question Number 
Frequency of correct answer in the post-test of students in the control group has increased in other questions except for 16th (see Figure 5). After application, increasing of frequency of correct answer in each question in the post-test suggests that method used in the control group is effective.

Table 5 Dependent T-Test Results of Experimental Group

\begin{tabular}{lccccc}
\hline Experimental Group & $N$ & $\bar{X}$ & $s d$ & $t$ & $p$ \\
\hline Pre-Test & 30 & 31,85 & 17,56 & $-12,93$ & 0,00 \\
Post-Test & 30 & 62,41 & 17,43 & & \\
\hline
\end{tabular}

Experimental group's pre-test score mean is 31,85 and this group's standard deviation is 17,56 , this group's post-test score mean is 62,41 and this group's standard deviation is 17,43 (see Table 5). The difference between experimental group's pre- and post-tests score means is 30,56 , this difference is statistically significant because of $p<0,03$. The results obtained at the end of the application show that the experimental instruction is effective.

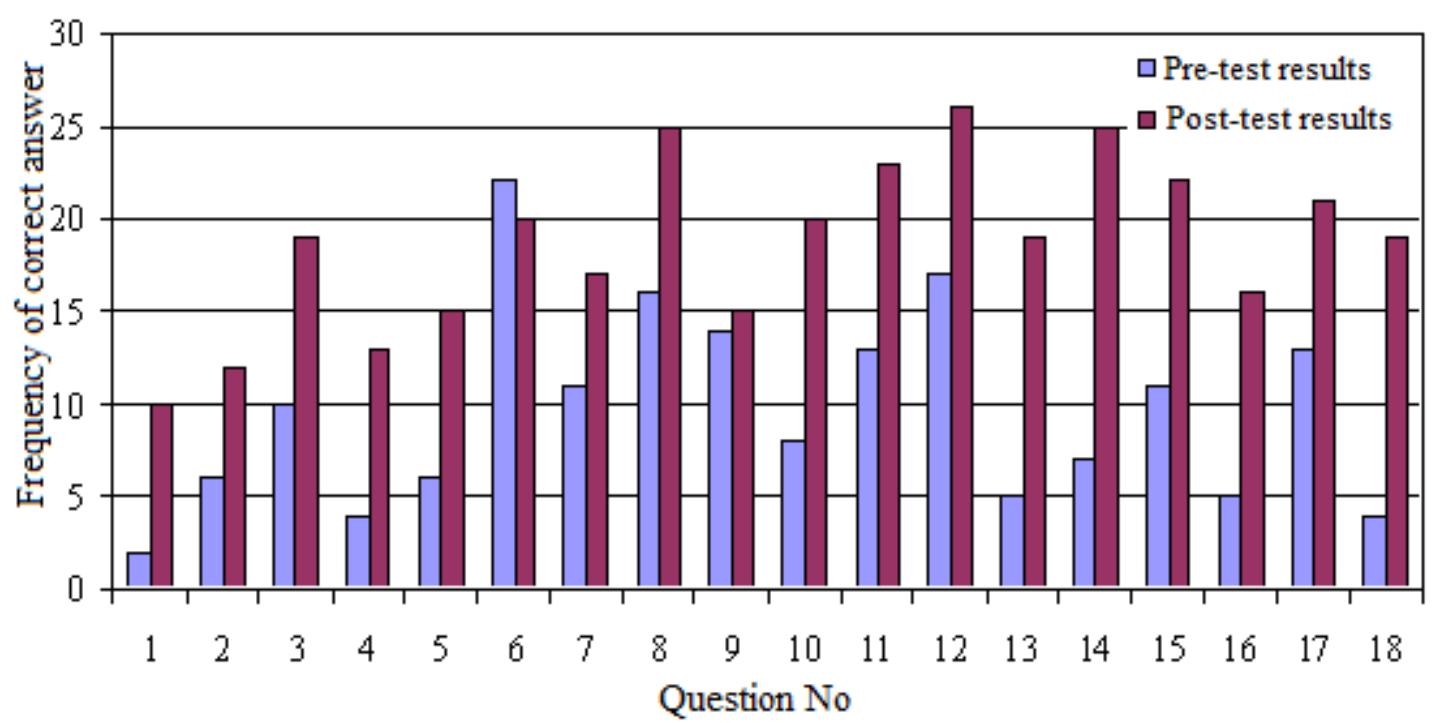

Figure 6 Pre-test and Post-test Frequency of Correct Answer of Experimental Group Students According to Question Number

After application, there is a significant increase in the frequency of correct answer of students in the experimental group (see Figure 6). This case reveals that application which uses the model is effective in teaching of concepts such as "the real and the apparent motions of the Sun-Earth-Moon and the results of these motions". Result which experimental group's post-test frequency of correct answer is more than this group's pre-test frequency of correct answer in all items except 6 th questions show that using the model in concepts related to this questions is effective. 
Table 6 Independent T-Test Results Toward Post-Test Scores

\begin{tabular}{lccccc}
\hline Group & $N$ & $\bar{X}$ & $s d$ & $t$ & $p$ \\
\hline Experimental Group & 30 & 62,41 & 17,43 & 2,64 & 0 \\
Control Group & 30 & 50,93 & 16,12 & \\
\hline
\end{tabular}

While the experimental group's post-test score mean is 62,41 and this group's standard deviations is 17,43 , the control group's post-test score mean is 50,93 and this group's standard deviations is 16,12 (see Table 6). The difference between experimental group's and control group's post-tests score means is 11,48 , this difference is statistically significant because of $p<0,03$. It reveals that experimental instruction that use Sun-Earth-Moon Model is more effective than standard instruction in describing of concepts (above mentioned).

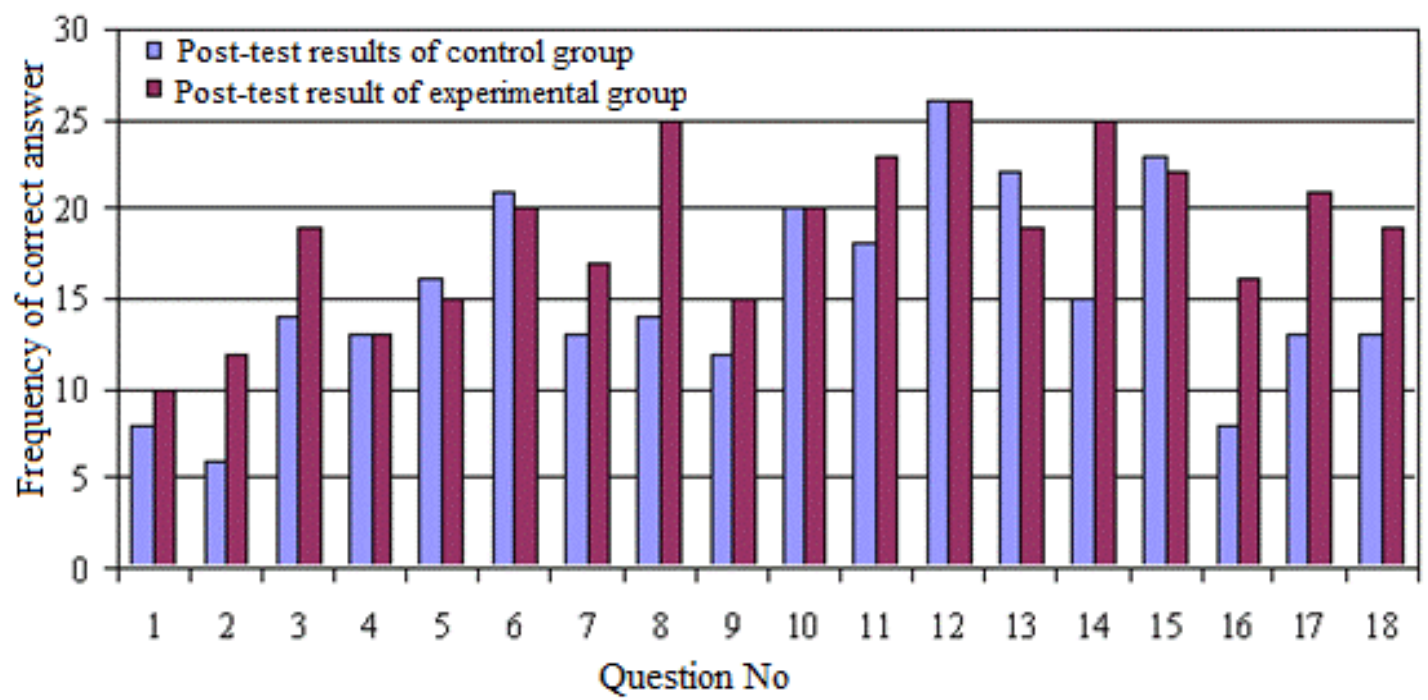

Figure 7 Post-test Frequency of Correct Answer of Experimental and Control Groups Students According to Question Number

After the application, it is seen that there is a difference in the number of correct answers to the questions of the experimental and control groups (see Figure 7). Especially, result that there is statistically differences between groups in favor of the experimental group in the 1st, 2nd, 3rd, 7th, 8th, 9th, 11th, 14th, 16th, 17th and 18th question suggests that using the model is effective in concepts related to this questions.

\section{Conclusion and Discussion}

Intangible context of science and astronomy that is sub-branch of science reveals the need that use training aids such as pictures, posters, CDs, videos and model in describing astronomy concepts. Using standard methods such as straight narration and question-andanswer prevents understanding of concepts which require comprehending three-dimensional relationships and imagination skill and they lead to misconception. 
As discussed in the results section, Sun-Earth-Moon Model that was used in experimental group reveals that increases understanding of these concepts that relies on perceiving three-dimensional relationships and intangible thinking and three-dimensional because later application, there was increase of frequency in favor of the experimental group in concepts such as "Moon phases" that explored in the 1st and 2nd questions, "the Earth's motion around the Sun" that explored in the 8th question, "axis tilt and the Earth's motion around the Sun " that explored in the 11th question, "axis tilt" that explored in the 12th question, "lunar and solar eclipse" that explored in the 13th, 14th, 16th, 17th and 18th questions. At this point, thanks to using the model, students will have an opportunity to observe and touch it and will resolve questions toward intangible concepts about basic astronomy. According to us, through model, comprehension of related concepts will be easier and will turn into being concrete from being intangible and thus the effectiveness of training will increase. Also, as a result of observations, it has been identified that the developed SunEarth-Moon Model in this study which is a concrete example of related concept drawn attention to students, arouse curiosity to concept, kept interest fresh, whipped up willingness of work. In addition, it has been determined that concepts described in a shorter time on the developed the model. For this reason, models shorten the learning time by saving from time.

Both experimental and control group, there were frequency increases in concepts such as "the Moon's rotation and revolution around the Earth" that explored in the 3rd question, "the Moon's real and apparent periods" that explored in the 4th question, "the Earth's elliptical orbit" that explored in the 5th question, "formation reason of seasons" that explored in the 7th question, "the Sun's apparent movement" that explored in the 9th question, "the Earth's movement around the Sun" that explored in the 10th question, "the Sun eclipse" that explored in the 15th question requires later implementation. However, being frequency increase in favor of the control group are connected to some possibilities such as that related concept could be answered by memorizing with standard instruction (3rd, 4th, 5th, 7th, 9th and 15th questions), that related concept could be described theoretically at the twodimensional plane (4th question), that the Earth's speed remains constant as it revolves around the Sun on its elliptical orbit and the Earth's axis stability during orbit motion could not be set as mentioned in "Limitations of model" section (5th and 10th questions), that information about related concept are present in student (15th question). After the implementation, in "the Earth's axial tilt" concept that explored in the 6th question, while the control group showed an increase in the frequency, there was a decrease in the frequency of 
experimental group. This case connected to that the Earth's speed remains constant as it revolves around the Sun on its elliptical orbit could not be set as mentioned in "Limitations of model" section.

The model used in the research is more complex and detailed than the other models in the literature because it can explain all the basic astronomy issues and show both of axial and orbital motions. Therefore, considering the literature review, the developed model is considered to be superior to other models. That is, in spite of its all limitations, it is the best model compared to other models found in the literature.

With this model, saving time in learning, retention and student participation will be provided. Thus, better understanding of event and phenomenon which cannot be gone to its side and cannot be brought to class will be provided.

With this study, we think that developed Sun-Earth-Moon Model will give idea to the other models which will be developed in this field and this study will enlighten other studies which effect students' achievement of educational material using will examine.

\section{References}

Balkan, A. (2007). The effects of using maps on lesson behaviors, achievement and memorization level in social studies to the seventh grade primary students. Unpublished master's thesis. Sakarya University, Sakarya.

Baloğlu-Uğurlu, N. (2005). Misconceptions of the 6th year students of primary education on the Earth and the universe. Journal of Gazi Education Faculty, 25(1), 229-246.

Bostan, A. (2008). Different age group students' ideas about some basic astronomy concepts. Unpublished master's thesis. Balıkesir University, Balıkesir.

Chiras, A. \& Valanides, N. (2008) Day/night cycle: Mental models of primary school children. Science Education International, 19(1), 65-83.

Clark, D.C. \& Mathis, P.M. (2000). Modeling mitosis \& meiosis: A problem-solving activity. The American Biology Teacher, 62(3), 204-206.

Diakidoy, I.A.N. \& Kendeou, P. (2001). Facilitating conceptual change in astronomy: A comparison of the effectiveness of two instructional approaches. Learning and Instruction, 11, 1-20. 
Falcao, D., Colinvaux, D., Krapas, S., Querioz, G., Alves, F., Cazelli, S., Valente, M.E. \& Gouvea, G. (2004). A model-based approach to science exhibition evaluation: A case study in a Brazilian astronomy museum. International Journal of Science Education, 26(8), 951-978.

Frede, V. (2006). Pre-service elementary teacher's conceptions about astronomy. Advances in Space Research, 38(10), 2237-2246.

Frede V. (2008). Teaching astronomy for pre-service elementary teachers: A comparison of methods. Advances in Space Research, 42(11), 1819-1830.

Gözmen, E. (2008). The effects of the models on learning the subject "mitosis division" instructed in biology lessons at 10th grades of high schools. Unpublished master's thesis. Selçuk University, Konya.

Günbatar, S. \& Sarı, M. (2005). The model development for difficult concepts that can be understood in electricity and magnetism concepts. Journal of Gazi Education Faculty, 25(1), 185-197.

Güneş, M.H. \& Çelikler, D. (2010). The investigation of effects of modeling and computer assisted instruction on academic achievement. International Journal of Educational Researchers (IJER), 1(2), 22-28.

Kikas, E. (1998). The impact of teaching on students' definitions and explanations of astronomical phenomena. Learning and Instruction, 8(5), 439-454.

Koçak, E. (2006). The effect of model teaching on 'digestion and related structures', 'excretion and related structures' and 'recognizing of flowery plants' subjects in 5th grade students of primary education on the success of students. Unpublished master's thesis. Atatürk University, Erzurum.

Kurtkaya, S. (2010). Requirement of material usage and geography classes in secondary school geography education. Unpublished master's thesis. Marmara University, İstanbul.

Lee, C.B., Jonassen, D. \& Teo, T. (2011). The role of model building in problem solving and conceptual change. Interactive Learning Environments, 19(3), 247-265.

Lelliott, A. \& Rollnick, M. (2010). Big ideas: A review of astronomy education research 1974-2008. International Journal of Science Education, 32(13), 1771-1799. 
Minasl1, E. (2009). The effect of using model and simulation teaching techniques on the achievement, concept learning and remembering in the unit of structure and properties of matter. Unpublished master's thesis. Marmara University, İstanbul.

Ogan-Bekiroğlu, F. (2007). Effects of model-based teaching on pre-service physics teachers' conceptions of the Moon, Moon phases, and other lunar phenomena. International Journal of Science Education, 29(5), 555-593.

Pringle, R.M. (2004). Making it visual: Creating a model of the atom. Science Activities: Classroom Projects and Curriculum Ideas, 40(4), 30-33.

Samarapungavan, A., Vosniadou, S. \& Brewer, W.F. (1996). Mental models of the Earth, Sun and Moon: Indian children's cosmologies. Cognitive Development, 11, 491-521.

Sarıkaya, R., Selvi, M. \& Doğan-Bora, N. (2004). The importance effect of the use of models in teaching of mitosis and meiosis concepts. Kastamonu Education Journal, 12(1), 8588.

Subramaniam, K. \& Padalkar S. (2009). Visualization and reasoning in explaining the phases of the Moon. International Journal of Science Education, 31(3), 395-417.

Taber, K.S. (2001). When the analogy breaks down: modeling the atom on the solar system. Physics Education, 36(3), 222-226.

Taylor, I., Barker, M. \& Jones, A. (2003). Promoting mental model building in astronomy education. International Journal of Science Education, 25(10), 1205-1225.

Tunca, Z. (2002). Yesterday and today of astronomy education and teaching in primary and secondary education in Turkey. Paper presented at the V. National Science and Mathematics Education Congress, September 16-18, Ankara, Turkey.

Ünal, İ. \& Özdemir, İ. (2016). Three in one: The model of Sun-Earth-Moon. SHS Web of Conferences (ERPA2015), 26, 01116. https://doi.org/10.1051/shsconf/20162601116.

Ünsal, Y., Güneş, B. \& Ergin, İ. (2001). A study to investigate the fundamental astronomy knowledge levels of undergraduate students. Gazi Education Faculty Journal, 21(3), 47-60.

Vosniadou, S., Skopeliti, I. \& Ikospentaki, K. (2004). Modes of knowing and ways of reasoning in elementary astronomy. Cognitive Development, 19, 203-222.

Zeynelgiller, O. (2006). The effect of the use of models in chemistry subject of science lesson in secondary schools on students' success. Unpublished master's thesis. Celal Bayar University, Manisa. 


\section{Appendix}

\section{Achievement Test for Real and Visible Movements of Sun, Earth and Moon and Consequences of These Movements}

This test has been prepared as a requirement of a scientific research and won't affect your grade. Your responses to these questions sincerely will help to reach the most accurate results. I wish being sincere of answers that you will give, I would like thank you for your attention and contribution.

\section{Q U E S T I O N S}

1) Which of the following is true with regard to the Moon's phases?

A) Solar eclipse occurs in every new moon phase.

B) At the first quarter, the Moon rises after 12 hours from Sun.

C) At a full moon phase, the Moon arises from the horizon at midnight.

D) At the third quarter phase, the Moon remained from the Sun 18 hours. $\checkmark$

E) The Moon is seen on the horizon at the new moon phase.

2)

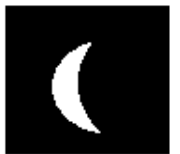

If the new moon phase is accepted as $1^{\text {st }}$ day of the month in the lunar calendar, when the Moon arises as shown from the horizon which day of month may be?
A) $1-8$
B) $8-15$
C) $15-21$
D) 21
E) $22-29 \sqrt{ }$

3) Which of the following is a reason to always appear the same face of the Moon?

A) Rotation period of the Moon around its axis and orbital period around the Earth are about 27,3 days. $\sqrt{ }$

B) Rotation of the Moon around its axis is as does of the Earth.

C) The Moon has an axial tilt.

D) $5^{\circ} 8^{\prime}$ angle which is between the Moon's and Earth's orbit.

E) 27,3 days which is the Moon's orbital period around the Earth.

4) What is the reason why the Moon's apparent orbital period longer than its real orbital period around the Earth?
A) $5^{\circ} 8^{\prime}$ angle which is between the Moon's and Earth's orbit.
B) The Earth's $23^{\circ} 27^{\prime}$ axial tilt.
C) The Moon's axial tilt.
D) Moon's motion with the Earth around the Sun. $\sqrt{ }$
E) The elliptical orbit of the Moon around the Earth.

5) Which of the following is a result of being the Earth's elliptical orbit around the Sun?

A) Seasonal periods are not equal. $\sqrt{ }$

B) Changing the angle of incidence from the Sun rays to the Earth continuously.

C) Occurrence of seasons.

D) Coming vertical only points between the tropics of the Sun ray.

E) Changing the length of day and night continuously.

6) Which of the following is not a result of the Earth's axial tilt $\left(23^{\circ} 27^{\prime}\right)$ ?

A) On June 21, the sunset time at the Northern Hemisphere is later than that of the Southern Hemisphere.

B) While the winter is lived in the Northern Hemisphere, the summer is lived in the Southern Hemisphere.

C) Speed of the Earth at January 3 is more than the other days. $\sqrt{ }$

D) The Sun will be at the zenith of Southern tropic on 21 December.

E) The Sun doesn't set on 186 days in the North Pole.

7) Which of the following is a cause of occurring seasons?
A) Changing of the distance from Earth to the Sun.
B) The Earth's axial tilt. $\sqrt{ }$
C) Variation of energy emitted from the Sun
D) Being elliptical of the Earth's orbit.

E) All 
8) Which of the following is false related to the Earth's motion around the Sun?

A) On 21 March, time of day and night are equal in the Southern Hemisphere.

B) The Earth revolves in the counterclockwise direction around the Sun.

C) At the point where the Earth is the closest to the Sun, summer is lived in the Southern Hemisphere.

D) Orbit is ellipse and elliptical plane is also called the eclipse plane.

E) The Sun sets as the closest to the north in the Southern Hemisphere on December 21. $\sqrt{ }$

9) Which of the following is not a result of the Sun's apparent movement?

A) Night-day periods changes all of year and this period increases when it is come from the equator to the poles.

B) The sun rise and set at the point of horizon are different every day all of year.

C) Sunrise and sunset times change constantly.

D) On June 21, the Sun is at the zenith of Turkey. $\sqrt{ }$

E) Day and night times are more than 24 hours at the North and South Pole points.

10) Which of the following is false considering Earth's motion around the Sun?

A) Angle between the Earth's axis and the orbital plane' normal is fixed.

B) On December 21, portion of the Earth's total enlightenment is the least. $\sqrt{ }$

C) January 3 is the date which Earth is the closest to the Sun on the orbit.

D) The Sun rays come to equator vertically on September 23 and March 21.

E) Angle between the Earth's equator plane and the eclipse plane doesn't change according to seasons.

11) Which of the following is a cause of changing of night-day periods?
A) Changing of the distance from Earth to the Sun.
C) Variation of energy emitted from the Sun.
B) The Earth's axial tilt. $\sqrt{ }$
D) Being elliptical of the Earth's orbit.

E) Rotation of the Earth around its axis.

12) Which of the following cannot be said, if it is accepted the Earth doesn't have tilt of axis while the Earth rotates around the Sun?

A) While summer is lived in the Northern Hemisphere, winter is lived in the Southern Hemisphere. $\sqrt{ }$

B) The Sun is seen from both the north and south poles of the Earth.

C) Light and dark areas in the Northern and Southern Hemispheres are equal to each other.

D) The Sun rays arrive at vertical angle to the equator.

E) Day and night times are equal to everywhere in the World.

13) Which of the following is not a cause of not to being lunar eclipse in the every full moon phase?

A) Angle between the Moon's orbit plane and the Earth's orbit plane is $5^{\circ} 8^{\prime}$.

B) Not to be the Sun, Earth and Moon in same line.

C) $6^{\circ} 41^{\prime}$ inclination of the Moon's axis. $\sqrt{ }$

D) Chance which the Moon may pass bottom or top of Earth's orbit.

E) Chance which the Moon take place outside of the Earth's shadow cone.

14) Why solar eclipse does viewed from west longitudes firstly?

A) Because the Moon rotates counterclockwise around the Earth. $\sqrt{ }$

B) Because the Earth rotates counterclockwise around the Sun.

C) Because the Earth turns on its axis from west to east.

D) Because the Earth's tilt of axis is curved $23^{\circ} 27^{\prime}$.

E) Because the axial tilt of the Earth and Moon are in different directions.

15) Which of the following is a cause of solar eclipse doesn't observe anywhere in the World?

A) Because the Earth rotation around its axis.

B) Because the Moon is smaller than the Earth. $\sqrt{ }$

C) Because the Moon revolves around the Earth.

D) Because the angle between the Moon's orbit plane and the Earth's orbit plane is $5^{\circ} 8^{\prime}$

E) Because the Moon's axis is curved $6^{\circ} 41^{\prime}$.

16) Which of the following is a cause of not to being lunar eclipse in the every full moon phase?

A) Because the Earth's shadow cone doesn't occur in the full moon.

B) Because the lunar eclipse occurs in the new moon.

C) Because the Sun doesn't seen in the full moon.

D) Because three body don't be same line.

E) Because the Moon's and the Earth's orbit plane are different? $\sqrt{ }$ 
17) When the total solar eclipse occurs, how does person who stands on Moon's surface facing the World see total shadow cone in the Earth?

A)

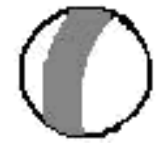

B)

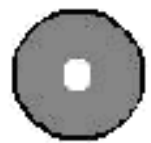

C)

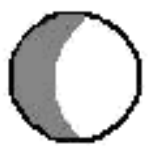

D)

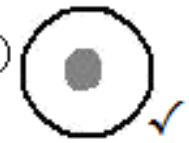

E)

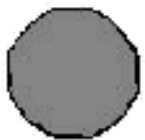

18) Which of the following is a cause of not to being solar eclipse in the every new moon phase?

A) Because the Moon doesn't seen in the every new moon phase.

B) Because solar eclipse occurs in the full moon.

C) Because the Moon passes from bottom or top of elliptical plane. $\sqrt{ }$

D) Because three body don't be on the same line.

E) Because the Earth's shadow cone doesn't occur in the new moon phase. 